\title{
Non-invasive molecular sexing: an evaluation and validation of the SRY- and amelogenin-based method in three new lemur species
}

\begin{tabular}{|r|l|}
\hline Journal: & American Journal of Physical Anthropology \\
\hline Manuscript ID: & AJPA-2012-00274.R1 \\
\hline Wiley - Manuscript type: & Technical Note \\
\hline Date Submitted by the Author: & n/a \\
\hline Complete List of Authors: & $\begin{array}{l}\text { Vanpé, Cécile; Instituto Gulbenkian de Ciência, } \\
\text { Salmona, Jordi; Instituto Gulbenkian de Ciência, } \\
\text { Pais, Isa; Instituto Gulbenkian de Ciência, } \\
\text { Kun-Rodrigues, Célia; Instituto Gulbenkian de Ciência, } \\
\text { Pichon, Claire; UMR 7206, Eco-anthropologie et Ethnobiologie, CNRS and } \\
\text { MNHN, } \\
\text { Viana Meyler, Sam; Instituto Gulbenkian de Ciência, } \\
\text { Rabarivola, Clément; Université de Mahanjanga, Campus Universitaire } \\
\text { Ambondrona, Faculté des Sciences } \\
\text { Lewis, Rebecca; University of Texas, Department of Anthropology } \\
\text { Ibouroi, Mohamed; Université de Mahanjanga, Campus Universitaire } \\
\text { Ambondrona, Faculté des Sciences } \\
\text { Chikhi, Lounes; Instituto Gulbenkian de Ciência, ; CNRS UMR 5174 EDB, }\end{array}$ \\
\hline Key Words: & $\begin{array}{l}\text { PCR-based sex test, non-invasive samples, Propithecus, Microcebus, } \\
\text { multiple-tubes approach }\end{array}$ \\
\hline
\end{tabular}


1 Non-invasive molecular sexing: an evaluation and validation of the SRY- and amelogenin-

2 based method in three new lemur species

3 Cécile Vanpé ${ }^{1, *}$, Jordi Salmona ${ }^{1}$, Isa Pais ${ }^{1}$, Célia Kun-Rodrigues ${ }^{1}$, Claire Pichon ${ }^{2}$, Samuel

4 Viana Meyler ${ }^{1}$, Clément Rabarivola ${ }^{3}$, Rebecca J. Lewis ${ }^{4}$, Mohamed Thani Ibouroi ${ }^{3}$ and

5 Lounès Chikhi ${ }^{1,5}$

$6{ }^{1}$ Instituto Gulbenkian de Ciência, Rua da Quinta Grande, no. 6, 2780-156 Oeiras, Portugal

7 (Institution from which the paper emanated)

$8 \quad{ }^{2}$ UMR 7206, Eco-anthropologie et Ethnobiologie, CNRS and MNHN, 4 avenue du Petit

9 Château, 91800, Brunoy, France

$10{ }^{3}$ Université de Mahanjanga, Faculté des Sciences, Campus Universitaire Ambondrona BP

11652401 Mahajanga, Madagascar

$12{ }^{4}$ Department of Anthropology, University of Texas, Austin, Texas, USA

$13 \quad{ }^{5}$ CNRS UMR 5174 EDB, 118 route de Narbonne Toulouse, France

1424 pages of text from title to acknowledgements +7 pages of literature cited, 1 figure, 5 tables

15 Abbreviated title: Non-invasive molecular sexing in lemurs

16 Key words: PCR-based sex test; non-invasive samples; Propithecus; Microcebus; multiple-

17 tubes approach

18 *Correspondence to: Dr Cécile Vanpé, Instituto Gulbenkian de Ciência, Rua da Quinta

19 Grande, no. 6, 2780-156 Oeiras, Portugal. Phone: (+351) 214464669. Fax: (+351) 21

20 4407970. E-mail: cecile_vanpe@yahoo.fr

21 Grant sponsors: Fundação para a Ciência e a Tecnologia" (ref. PTDC/BIA-BEC/100176/2008

22 and SFRH/BPD/73675/2010); Institut Français de la Biodiversité (ref. CD-AOOI-07-003),

23 Programme Biodiversité de l'Océan Indien (ref. CD-AOOI-07-003); "Laboratoire

24 d'Excellence (LABEX)" entitled TULIP (ref. ANR -10-LABX-41); Instituto Gulbenkian de

25 Ciência; Optimus!Alive-IGC fellowship; UMR 7206 - CNRS. 
26 ABTSRACT Many lemur species are arboreal, elusive and/or nocturnal and are

27 consequently difficult to approach, observe and catch. In addition, most of them are

28 endangered. For these reasons, non-invasive sampling is especially useful in primates

29 including lemurs. A key issue in conservation and ecological studies is to identify the sex of

30 the sampled individuals to investigate sex-biased dispersal, parentage, social organization and

31 population sex ratio. Several molecular tests of sex are available in apes and monkeys, but

32 only a handful of them work in the lemuriform clade. Among these tests, the co-amplification

33 of the SRY gene with the amelogenin X gene using strepsirhine-specific X primers seems

34 particularly promising, but the reliability and validity of this sexing test have not been

35 properly assessed yet. In this study, we (i) show that this molecular sexing test works on three

36 additional lemur species (Microcebus tavaratra, Propithecus coronatus and P. verreauxi)

37 from two previously untested genera and one previously untested family, suggesting that

38 these markers are likely to be universal among lemurs and other primates; (ii) provide the first

39 evidence that this PCR-based sexing test works on degraded DNA obtained from non-

40 invasive samples; (iii) validate the approach using a large number of known-sex individuals

41 and a multiple-tubes approach, and show that mismatches between the field sex and the final

42 molecular consensus sex occur in less than $10 \%$ of all the samples and that most of these

43 mismatches were likely linked to incorrect sex determinations in the field rather than

44 genotyping errors. 
Non-invasive samples, such as feces and hairs, are particularly valuable in primates because most species are arboreal, highly mobile and elusive, which makes them difficult to catch in the wild for the purpose of collecting blood or other tissue samples (e.g., Goossens et al., 2000, 2002). In addition, nearly half of the 634 recognized primate species and subspecies face extinction (Mittermeier et al., 2009) which makes non-invasive sampling techniques desirable to avoid the negative impact of animal captures and excessive handling (Waits and Paetkau, 2005).

Since the first successful attempts of DNA extraction and amplification from noninvasive samples on free-ranging mammals (Höss et al., 1992; Taberlet and Bouvet, 1992; Taberlet et al., 1993, 1996; Woodruff, 1993; Constable et al., 1995; Gerloff et al., 1995; Gagneux et al., 1997; Goossens et al., 1998), non-invasive molecular techniques have been increasingly used in primates for investigating issues as diverse as parentage, dispersal and kinship (e.g., Morin et al., 1994; Gerloff et al., 1999; Constable et al., 2001; Oka and Takenaka, 2001), genetic structure and diversity (e.g., Reinartz et al., 2000; Eriksson et al., 2004; Quéméré et al., 2010), phylogeography (e.g., van der Kuyl and Dekker, 1996; JensenSeaman and Kidd, 2001) or population censuses (e.g., Bergl and Vigilant, 2007; Guschanski et al., 2009).

For such non-invasive studies, identifying the sex of the sampled individuals can be a key issue to infer and quantify sex-biased dispersal (e.g., Bradley et al., 2004; Eriksson et al., 2006), assign parentage, build pedigrees and study the mating system and social structure (e.g., Vigilant et al., 2001; Bradley et al., 2005; Boesch et al., 2006) or determine the population sex ratio (e.g., McGrew et al., 2004). Incorporing sex-related information into ongoing analyses of fecal or hair samples (Bradley et al., 2001) can also be important to determine, for instance, whether there are sex-related biases in parasite load (LandsoudSoukate et al., 1995) or diet (Marriott et al., 1996). Even when animals can be observed or 
70 handled in the field, sex identification can be difficult because of the limited sexual

71 dimorphism between males and females (especially at the juvenile stage) in some species

72 (Ensminger and Hoffman, 2002). Molecular sexing may be necessary to confirm sex

73 determination in the field (Griffiths and Tiwari, 1993).

74 The general method used to molecularly identify the sex of sampled individuals is based

75 on the PCR amplification of sex-specific regions, followed by the visualization of the PCR

76 products using a standard electrophoresis (Villesen and Fredsted, 2006a). Basically, two main

77 approaches have been developed in mammals (Fernando and Melnick, 2001): 1) the

78 amplification of a homolog region on the $\mathrm{X}$ and $\mathrm{Y}$ chromosomes with known length

79 polymorphism between sexes, such as the amelogenin gene "AMEL" (e.g., Bradley et al.,

80 2001; Ensminger and Hoffman, 2002; Fredsted and Villesen, 2004), the zinc finger protein

81 gene (e.g., Wilson and Erlandsson, 1998; Fernando and Melnick, 2001), the ubiquitously

82 transcribed tetratricopeptide repeat protein gene "UTX/UTY" (Villesen and Fredsted, 2006b)

83 and the Dead-Box gene (Villesen and Fredsted, 2006a) in primates; 2) the coamplification of

84 a Y-specific region (i.e. the sex determination region $\mathrm{Y}$ gene "SRY" in primates) with an

85 autosomal or an X-linked marker (e.g., Amelogenin X gene, Di Fiore, 2005).

86 Until recently, no test was specifically available for the molecular sexing of lemurs (see

87 Table 1 for more details). Indeed, because the lemuriform clade diverged from other primates

88 more than 60 million years ago (Nowak, 1999), most primers designed for humans, great and

89 lesser ape or Old and New World monkey species could not amplify lemur DNA successfully

90 because of the mutation accumulation since the divergence time (Fredsted and Villesen,

91 2004).

92 By co-amplifying the SRY gene with the amelogenin X gene using strepsirhine-specific

$93 \mathrm{X}$ primers and using high quality DNA extracted from tissue and blood, Di Fiore (2005)

94 managed to determine the sex of three sampled individuals from three different lemur species: 
Lemur catta, Daubentonia madagascariensis and Mirza coquereli. While this method

potentially provides a promising protocol, it still requires further testing and validation. First, lemurs are subdivided into five major families, two of which (Lepilemuridae and Indriidae) were not represented in the original study, and extending the tests to other species from the same and from new families is thus necessary. Second, all the samples used were from tissue and the performance of the sexing test with degraded DNA obtained from hair or feces is unknown. Third, only the samples of the first two species were from known-sex individuals making the sexing of the third species difficult to validate. Fourth, the assessment of the sexspecificity nature of the sexing test was based on only one male individual for each of the two species with known-sex sample (no female was tested). Finally, the accuracy of the test was not quantified by molecularly sexing a reasonably large number of known-sex individuals for each species (see Robertson and Gemmell, 2006 for a discussion on this issue).

Our study therefore aims at further assessing the reliability and validity of Di Fiore's approach to determine the sex of lemurs, especially when dealing with non-invasive samples, which are likely to become increasingly available for many endangered species due to the fact that technological advances now allow to use fecal samples for metagenomic studies (Pompanon et al., 2012; Sharma et al., 2012). In particular, we: (i) tested this approach on three new lemur species (Microcebus tavaratra, Propithecus coronatus and P. verreauxi), from two new genera and one new family, (ii) tested whether this method works with noninvasive samples, (iii) validated the approach using known-sex individuals (from field observation and captures) and estimated the rate of mismatching between field and molecular sexing results, and (iv) evaluated the number of replicates necessary for reliable molecular sex assignments by repeating amplifications of individual samples via a multiple-tubes approach (Taberlet et al., 1996) that is commonly used for genotyping but not for sexing. 


\section{MATERIALS AND METHODS}

\section{Sampling}

We studied three lemur species from Madagascar, one mouse lemur (Microcebus tavaratra) considered as endangered, and two sifakas (Propithecus coronatus and $P$. verreauxi) considered respectively as endangered and as vulnerable by The IUCN Red List of Threatened Species, 2012.1 (http://www.iucnredlist.org/).

The mouse lemur samples were obtained in July-August 2010 in the Daraina region (Northern Madagascar, Meyler et al., 2012) using Sherman traps (H.B. Sherman Traps $\left.{ }^{\circledR}\right)$ to capture individuals. For each individual captured, skin tissue samples (ca. $2 \mathrm{~mm}^{2}$ ) were taken using a specific 1-3 systematic ear biopsy code (following Rakotondravony et al., 2009) for later individual identification. The biopsies were stored in Queens Lysis Buffer (Seutin et al., 1991; Dawson et al., 1998) until extraction, first in Madagascar at room temperature and then in Lisbon at $4^{\circ} \mathrm{C}$ (see Table 2 for more details). Morphometric measures were taken and the sex was recorded for all individuals from visual inspection of the genitalia. In this study, 75 samples (49 identified in the field as females and 26 as males) were used for the sex identification and validation procedure.

For the two sifaka species, fecal samples were obtained non-invasively just after defecation from known individuals belonging to social groups that are being followed for behavioral, ecological and evolutionary studies (Pichon et al., 2010; Lewis and Rakotondranaivo, 2011). For P. coronatus, the sex was known from distant but repeated observation of the genitalia and 65 (35 identified in the field as females and 30 as males) individuals were sampled in July-August 2010 in Antrema (Northwestern Madagascar). Note, however, that there were differences in the intensity and frequency of observations among $P$. coronatus individuals. For instance, eight samples from individuals identified in the field as females and six identified as males were the object of a more intensive behavioral study and 
144 were observed longer and more often in the field than the other 51 individuals. Their sex

145 could therefore be identified in the field with more confidence than for individuals from less

146 intensively observed social groups. The P. verreauxi individuals were easily identified by

147 nylon collars and numbered tags or radiocollars worn as a part of a long-term study of the

148 population. Thus, sex was based upon previous capture and handling of individuals. Eighteen

149 (10 identified in the field as females and eight as males) samples were obtained in June 2011

150 in the Ankoatsifaka field station of the Kirindi Mitea National Park (Central-Western

151 Madagascar).

152 All field handling and sampling procedures adhered to the legal requirements of

153 Madagascar and were approved by the Ministère de l'Environnement et des Forêts of

154 Madagascar and the Malagasy government permitting committee CAFF/CORE (permit ID:

155 175/10). The research was conducted with the approval of the USA, French, Portuguese

156 governments and was approved by the University of Texas at Austin's Institutional Animal

157 Care and Use Committee (permit ID: 08110301).

158

159

160

161

162

163

164

165

166

167

168

\section{DNA extraction and amplification}

For the fecal material, DNA extraction was performed following the 2CTAB/PCI protocol adapted from Vallet et al. (2008), according to Quéméré et al. (2010). For the Microcebus ear biopsies, total genomic DNA was extracted using a standard mammalian DNA isolation protocol adapted from Laird et al. (1991). Each sample was incubated overnight at $37^{\circ} \mathrm{C}$ in $300 \mu$ digestion buffer (100 mM EDTA, $100 \mathrm{mM} \mathrm{NaCl}, 50 \mathrm{mM}$ Tris $\mathrm{pH} 8$ and 1\% SDS) and $30 \mu \mathrm{l}$ of Proteinase $\mathrm{K}$ at $10 \mathrm{mg} / \mathrm{ml}$ (Promega \#V3021). The extractions were performed in a DNA free Hood and each set of samples included a negative control to ensure that no cross-contamination occurred and a positive control (i.e. one sample from the same species that had already amplified successfully) to validate the genotypes. We then 
169 quantified for each sample the extracted DNA using a Nanodrop (Thermo Scientific

170 Nanodrop 1000 spectrophotometer) (Table 2). Note that for fecal samples, the estimated

171 template DNA includes that of any organism (e.g., fungi, plants, bacteria) present in the feces

172 and is therefore not necessarily a reliable measure of lemur DNA.

173 Molecular sexing was performed using the two primer pairs published by Di Fiore (2005)

174 (strepsirhine-specific X primers AMEL-F1[strep]: 5'-TGGCCTCAAGCCTGCATT-3' and

175 AMEL-R1[strep]: 5'-AACATCYTACCTAATCCCCACA-3'; SRY primers SRY-F1: 5'-

176 AGTGAAGCGACCCA-TGAACG-3' and SRY-R1: 5'-TGTGCCTCCTGGAAGAATGG-

177 3'). A single multiplex PCR was performed to simultaneously amplify fragments of the

178 amelogenin X gene and the Y-linked sex-determining region (SRY) gene. While the SRY

179 locus is used to assign sex (amplifying only if a Y chromosome template is present) and

180 should yield a $\sim 165 \mathrm{bp}$ fragment (this varies between species), the amelogenin locus serves

181 as a positive PCR control and should be present in all samples with sufficient DNA,

182 producing a $\sim 200 \mathrm{bp}$ fragment. As a result, males are expected to produce two bands, whereas

183 females are expected to produce only one band.

$184 \quad$ For fecal samples, PCR amplification was carried out in a total volume of $10 \mu \mathrm{l}$

185 consisting of $5 \mu \mathrm{l}$ of $2 \mathrm{x}$ MyTaq HS Mix from Bioline, $0.1 \mu \mathrm{l}$ of each primer (for a final

186 concentration of $10 \mu \mathrm{M}$ ) and $1 \mu \mathrm{l}$ of total template DNA. For ear biopsy samples, we added

187 only half of the total volume of the above mix (i.e. $4.5 \mu \mathrm{l}$ ) to $1 \mu \mathrm{l}$ of total template DNA of

188 each sample.

189 PCR reactions were conducted in a BIO-RAD MyCycler ${ }^{\mathrm{TM}}$ Thermal Cycle under the

190 following conditions: for fecal samples, initial denaturation of $15 \mathrm{~min}$ at $94^{\circ} \mathrm{C}$, followed by 40

191 cycles of $94^{\circ} \mathrm{C}$ for $30 \mathrm{~s}, 60^{\circ} \mathrm{C}$ for $1 \mathrm{~min}$ and $72^{\circ} \mathrm{C}$ for $1 \mathrm{~min}$, and a final extension step for 10

$192 \min$ at $72^{\circ} \mathrm{C}$; for ear biopsies, initial denaturation of $15 \mathrm{~min}$ at $95^{\circ} \mathrm{C}$, followed by 30 cycles of

$19395^{\circ} \mathrm{C}$ for $30 \mathrm{~s}, 58.5^{\circ} \mathrm{C}$ for $90 \mathrm{~s}$ and $72^{\circ} \mathrm{C}$ for $1 \mathrm{~min}$, and a final extension step for $30 \mathrm{~min}$ at 
$72^{\circ} \mathrm{C}$. The PCR templates finally staid at $4^{\circ} \mathrm{C}$ until the gels were run. Electrophoresis was carried out on a $3 \%$ agarose gel for $35-40$ min at $90 \mathrm{~V}$, and the bands were visualized under a UV light using a RedSafe staining (RedSafeTM Nucleic Acid Staining Solution (20,000x) iNtRON Biotechnology, Inc) and a 100 bp Step ladder (PROMG6951-SC) (see Fig. 1 for an example of gel image). We defined a positive PCR according to Goossens et al. (2000), i.e. when a PCR product was obtained and alleles were identified.

\section{Multiple-tubes procedure and definition of the "true" sex}

A key issue when dealing with both field sex identification and molecular sexing determination is to decide what we consider as the "true" sex. Indeed, both sexing approaches can result in incorrect sex assignment. The misidentification of an individual's sex in the field can be caused by various factors such as bad conditions of observation (due for instance to animal distance and/or hiding in the foliage), ambiguous or subtle morphological sexing cues (especially in juveniles), or the widespread belief that only females carry infants, which is not true in all species (Ensminger and Hoffman, 2002). Molecular sexing can also provide incorrect sexing results for other reasons such as amplification failure due to technical (allelic dropout, null alleles or preferential amplification; Hoffman and Amos, 2005; Robertson and

Gemmell, 2006) or non-technical (primer region mutations or laboratory bookkeeping errors; Robertson and Gemmell, 2006; Villesen and Fredsted, 2006b) problems, false alleles (when amplification artifacts can be misinterpreted as true alleles), sporadic contaminations by human male manipulators or cross-sample contaminations (Taberlet et al., 1999; Goossens et al., 2000). A multiple-tubes procedure independently repeating amplifications of individual samples should allow for the detection of most of these problems and avoid incorrect sex assignment (Taberlet et al., 1996, 1999). Finally, both approaches may provide correct but apparently contradictory results. This situation occurs when field sexing is correct but there is 
219 mis-sampling of an individual's feces due to the simultaneity in several individuals'

220 defecations leading to the correct molecular sexing of the wrong individual. This problem is

221 crucial when one wants to estimate error rates and validate methods as we did in the present

222 study.

223 Our aim was therefore to follow the general multiple-tubes procedures suggested to 224 validate microsatellite markers genotyped from feces (e.g., Taberlet et al., 1996; Goossens et 225 al., 2005; Quéméré et al., 2010) and perform at least three independent replicates of the sexing 226 result (i.e. three positive PCRs) for each sample. Because of the degraded nature of the DNA

227 present in Propithecus fecal samples, several samples failed to amplify in some or all three

228 first PCR replicates. We therefore carried out additional PCRs and in some cases additional

229 DNA extractions (with a limit of 5-8 independent amplifications and three independent

230 extractions for a given sample) so as to achieve a minimum of three successful amplifications

231 (positive PCRs) per sample.

232 We used the following rules to score the final consensus molecular sex. The sex bands

233 had to appear at least three times over the different replicates to be considered as the final

234 consensus sex. Hence, whenever the sexing results of the three first positive PCRs were

235 consistent, we stopped doing additional PCRs and scored the final consensus sex. Whenever

236 an inconsistency in the sexing results occurred between the three first replicates, we

237 considered that the sexing results were ambiguous and we performed additional PCRs until

238 we obtained three similar sexing results out of four or five PCR repetitions. We must note

239 here that this approach may be problematic if the rate of sexing error is high. Indeed, after five

240 replicates a $3 / 5$ ratio favoring one sexing result is only marginally better than $50 \%$. In our

241 study where sexing error rates were very low this is not an issue.

242

243

\section{Estimation of the different error rates}


We compared the sex determined in the field with the molecular sex as determined after three consistent results of the positive PCRs and estimated the rate of mismatching between both sexing results.

Different genotyping errors could be identified by comparing individual PCRs and the final molecular sex: (i) Y fragment dropout, when the Y fragment was not amplified in males due to allelic dropout, (ii) $\mathrm{Y}$ spurious amplification, when the $\mathrm{Y}$ fragment amplified in females due to a contamination or an amplification artifact misinterpreted as a true allele. The $\mathrm{Y}$ fragment dropout and spurious amplification rates were thus calculated as the number of times the $\mathrm{Y}$ fragment dropped out in males and spuriously amplified in females, respectively, times 100 , divided by the total number of successful amplifications in males and females, respectively.

To evaluate the number of replicates necessary for reliable molecular sex assignments, we first estimated the percentage of positive PCRs among all replicates providing a different sexing result than the final molecular consensus sex (i.e. sex determined after at least three consistent results of the positive PCRs). We then considered two independent positive PCRs per sample and estimated the rate of sexing result mismatches between the two replicates (when the two replicates provided ambiguous sexing results). This rate was estimated by comparing the sexing results of the first with the second positive PCRs, as well as of the first with the third positive PCRs, but not of the second with the third positive PCRs since adding this last comparison would introduce a problem of non-independency between data. Finally, we estimated the percentage of samples with inconsistent molecular sexing results between the three first positive PCRs, and which therefore necessitated additional PCRs to obtain the final consensus sex. 


\section{RESULTS}

\section{Amplification success rate}

The proportion of positive PCRs out of the 508 PCR amplifications carried out overall for the study was $92 \%$, but the amplification success rate varied between species. For $M$. tavaratra ear biopsies, all extracted DNA amplified successfully at the first attempt (amplification success rate $=100 \%$ for a total of 228 PCRs performed). For $P$. verreauxi fecal samples, only one extract failed to amplify twice, but the second extract from the same sample amplified successfully for the three replicates (amplification success rate $=96.4 \%$ for a total of 56 PCRs performed). For $P$. coronatus fecal samples, the amplification success rate was much lower (about 83\%): 37 of 224 PCRs failed and these failures concerned 14 samples ( $22 \%$ of the 65 P. coronatus samples). Note that for these 14 samples, the amplifications were often tested on several independent extracts (1.6 extracts/sample on average, with a maximum of three extracts).

We obtained a minimum of three independent molecular sexing results (i.e. three positive PCRs) for a total of 154 out of the 158 individuals sampled among the three species, that is for $97.5 \%$ of all individuals (100\% for M. tavaratra and $P$. verreauxi, $94 \%$ for $P$. coronatus, Table 3). Two P. coronatus fecal samples could never give any specific PCR product despite five independent amplification attempts using three different DNA extracts. The other two $P$. coronatus fecal samples were only successfully amplified twice (Table 3) despite the use of five or six independent PCRs.

\section{Rate of mismatching between the field and molecular sexing results}

The rate of mismatching between the field and molecular sexing results was $9 \%$ over the three species (mismatchings occurred in 14 of the 154 individuals with three independent molecular sexing results), with important disparities between species (Table 4). While for $P$. 
292 verreauxi we observed no difference between the field and molecular sexing results, we 293 detected differences for five M. tavaratra (6.7\%) and nine P. coronatus (14.8\%) individuals

294 (Table 4). We also noticed that the mismatching rate was much higher in individuals assigned 295 to the male sex than to the female sex by the molecular sexing test in $M$. tavaratra $(13.8 \%$ vs. $2962.2 \%)$ and P. coronatus (22.9\% vs. 3.9\%, Table 4$)$. This result means that individuals finally 297 identified as males on the basis of the PCRs were more often identified as females in the field 298 than the opposite (identified males in the field that were genetically identified as females).

299

300

301

302

303

304

305

306

307

308

309

310

311

312

313

314

315

316

\section{Genotyping error rates for the Y chromosome}

Assuming that the sex determined after three consistent sexing results of the positive sexing PCRs was the "true" sex, we found that genotyping errors associated with non amplification of the $\mathrm{Y}$ allele were infrequent, and males were properly identified in more than $99 \%$ of the 216 PCRs over the three species (Table 4). The Y fragment dropped out only twice over 87 amplifications in $M$. tavaratra (dropout rate $=2.3 \%$ ), and never in $P$. coronatus and $P$. verreauxi (Table 4). Spurious amplification of the $\mathrm{Y}$ allele in DNA from a female occurred in only one of 246 PCRs over the three species (in a M. tavaratra sample), giving a very low global spurious amplification error rate of $0.4 \%$ (Table 4 ).

\section{Molecular sexing error rates}

Among the 154 individuals with at least three independent positive PCRs over the three species, only three positive PCRs, all from M. tavaratra samples, provided a different sexing result than the final consensus sex $(0.6 \%$ out of 493 positive PCRs over the three species or $1.3 \%$ out of 228 positive PCRs in M. tavaratra). When considering two positive PCRs per sample, the rate of sexing result mismatches between the two replicates was about $1.0 \%$ over the three species, $2.0 \%$ in $M$. tavaratra and still $0.0 \%$ in $P$. coronatus and $P$. verreauxi. 
317 Finally, the molecular sexing results were consistent over the three first replicates in 151

318 out of 154 individuals over the three species (98\%). For these individuals, the final consensus

319 sex could be determined unambiguously based on these three replicates: 70 individuals were

320 assigned to the male sex and 81 individuals were assigned to the female sex. The three

321 remaining $M$. tavaratra individuals showed inconsistent molecular sexing results between the

322 three first positive PCRs and required additional PCRs to obtain the final consensus sex. With

323 a single additional positive PCR, we managed to obtain three consistent molecular sexing

324 results and determined the final sexing consensus. Note that these three individuals were not

325 among the five individuals that had different sex assignments in the lab and field.

326 


\section{DISCUSSION}

In this study, we applied Di Fiore's (2005) approach to new lemur species and tested it with both non-invasive and tissue samples. We also assessed its reliability by comparing field sex identifications to the molecular sexing results using several independent PCRs. The results presented here are therefore of great importance to field biologists working on lemurs.

We note that most of the issues discussed here are actually valid across all vertebrates and thus to most field biologists interested in determining the sex of unknown individuals which cannot be reliably observed for long periods or for which only non-invasive samples are available.

Our study showed that Di Fiore's approach worked on M. tavaratra, P. coronatus and $P$. verreauxi and thus provides for the first time a way to molecularly determine the sex for these three lemur species. In his original study, Di Fiore had applied his approach on Lemur catta (Lemuridae), Daubentonia madagascariensis (Daubentonidae) and Mirza coquereli (Cheirogaleidae). Our study, by adding three species from two new genera and one new family (Indriidae), thus confirms that Di Fiore's molecular sex determination assay has been validated in at least one species of four out of the five families recognized in Madagascar (Mittermeier et al., 2008). This finding suggests that this approach may work on most if not all lemur species. It is noteworthy, though, that Fredsted and Villesen (2004) tried to sex $P$. verreauxi individuals using the Zinc finger protein system and the amelogenin gene system with degenerate primers but failed to obtain positive results on this species even though it worked on seven other lemur species (see Table 1). The fact that this other protocol was unsuccessful suggests that more tests should be performed across species, including the Lepilemuridae family not yet tested, and using different protocols.

Importantly, we also provided a validation of Di Fiore's lemur sexing protocol on reasonably large samples of known-sex individuals (from field observations and from 
352 captured animals) and the first evidence that it worked on degraded DNA obtained from non-

353 invasive samples (here fecal material), at least in the two Propithecus species studied. A high

354 rate of amplification success was observed using a large number of independent PCR

355 reactions from $M$. tavaratra ear biopsy extracts as well as from $P$. verreauxi fecal extracts,

356 with PCR products obtained in $100 \%$ and $96 \%$ of PCRs, respectively. In contrast, we had

357 more amplification failure problems for P. coronatus fecal samples (amplification success

358 rate $=83 \%$ ). In comparison, Vigilant (2002) demonstrated that the success rate of typing the

359 amelogenin locus from chimpanzee (Pan troglodytes) fecal samples dried with silica was on

360 average $>85 \%$. Bradley et al. (2001) reported some amplification success rates of the

361 amelogenin locus in chimpanzees (94\%) and gorillas Gorilla gorilla (97\%) fecal samples very

362 similar to what we found for $P$. verreauxi fecal extracts. The complete amplification success

363 that we found for M. tavaratra was expected because of the high quality DNA that can be

364 extracted from ear biopsies.

365 The differences in amplification success between the fecal samples of the two

366 Propithecus species are more striking. One hypothesis to explain this result is that sample

367 degradation has probably been more important in P. coronatus than in $P$. verreauxi fecal

368 samples. Indeed, while fecal samples from both species were collected fresh just after

369 defecation and then preserved dry in small tubes containing silica gel beads, $P$. coronatus

370 samples spent much more time in the field with important variations of temperature and

371 humidity and then in the lab at constant room temperature and humidity before DNA

372 extraction (total time between collection and extraction $=8-18$ months) than $P$. verreauxi ones

373 (total time $=4$ months, see Table 2 for more details). This hypothesis is also supported by the

374 lower DNA concentration measured with the Nanodrop in P. coronatus extracts than in $P$.

375 verrauxi, as well as the larger deviation of the $\mathrm{A}_{260 / 280}$ ratio from the optimal value (i.e.

376 between 1.8 and 2.0) observed in P. coronatus than in $P$. verreauxi, although the average 
$377 \mathrm{~A}_{260 / 280}$ values were similar in the two species (Table 2). Note, however, as mentioned above,

378 that for fecal samples, the estimated template DNA includes that of any organism (e.g., fungi,

379 plants, bacteria) present in the feces and is therefore not necessarily a reliable measure of

lemur DNA. The figures above should therefore not be taken as measures of lemur DNA

381

quantity but rather as proxies for total DNA quality (less degraded), including that of lemurs.

We validated and assessed the accuracy of Di Fiore's lemur PCR-based sex test by of known-sex individuals ( $>60$ for $M$. tavaratra, $P$. coronatus and 18 for $P$. verreauxi) and by independently repeating amplifications of individual samples at least three times (as recommended by Robertson and Gemmell, 2006). The results were in general very consistent: over the three species, field sex identifications and molecular sexing results (based on the final sexing consensus) were identical in more than $90 \%$ of all the samples. However, we found large differences across species in the mismatch rate between field and molecular sexing results (M. tavaratra: about 7\%, P. coronatus: $15 \%, P$. verreauxi: $0 \%)$.

For $P$. verreauxi fecal samples, we found that the field and molecular sexing results were all consistent, probably because all subjects had been captured and handled at some point prior to fecal sample collection. The $P$. verreauxi results are notable for demonstrating that Di Fiore's lemur PCR-based sex test is highly reliable even with low quality DNA extracted from non-invasive samples. Given that the time spent between collection and sexing seemed crucial, sexing (and most probably genotyping) should be conducted as soon as possible. For M. tavaratra ear biopsies, four individuals molecularly sexed as males and one individual molecularly sexed as a female were assigned the opposite sex in the field. This mismatch is likely due to sex misassignments in the field, because we followed a multipletubes procedure to assign the final molecular consensus sex, allowing for the detection of most genotyping errors. Although the sex of Microcebus individuals has been identified in the 
402 field after capture and handling of the animals, morphological sexing cues are sometimes

403 subtle. In particular, juvenile and subadult males with small testes can easily be misidentified

404 as females, likely explaining why these four males, with pretty low body mass (between 36

405 and $47 \mathrm{~g})$ compared to the average male body mass for this species $(50 \pm 5.6 \mathrm{~g}, \mathrm{n}=12$,

406 Radespiel et al., 2012; $49.7 \pm 7.4 \mathrm{~g}, \mathrm{n}=85$, Salmona et al. unpubl. data) and no swollen testes,

407 were misidentified as females in the field. The case of the female misidentified as a male in

408 the field is more difficult to explain. This could be due to a misspelling or the wrong

409 recording of the data.

$410 \quad$ Finally, for P. coronatus fecal samples, six individuals molecularly sexed as males and

411 one individual molecularly sexed as a female were assigned the opposite sex in the field. Most

412 of these sex mismatches are probably due to incorrect sex identification in the field because a

413 multiple-tubes approach was used. Indeed, all these seven individuals were part of the less

414 intensively followed social groups in the field for which the sex was identified with less

415 confidence than the most intensively followed social groups (see Materials and Methods). We

416 noticed that the mismatching rate was $18.0 \%$ for the less intensively observed individuals

417 whereas it was zero for the most intensively observed individuals. We found that the

418 mismatching rate between the field and molecular sexing results was much higher in

419 individuals assigned by the molecular sexing test to the male sex than to the female sex,

420 which could be explained by the fact that sifaka males are known to have particularly small

421 testes size for their body size (Lewis, 2009) and so can easily be misidentified as females in

422 the field, especially when they are juveniles. Interestingly, one of the six individuals identified

423 in the field as a female but as a male when using the molecular sexing test was observed

424 providing infant care. Paternal care in this species has never been reported but it has been

425 observed in several other Propithecus species (e.g., in P. coquereli: Bastian and Brockman,

426 2007, P. verreauxi: Lewis, 2004, P. tattersalli: Meyers, 1993, P. candidus: Patel, 2007). 
427 Hence, in that case, the widespread misconception that only females provide infant care and

428 can carry infants in most lemur species (Tecot et al. in press) might be the underlying cause

429 for incorrect sex assignment in the field. However, another potential explanation could be that

430 we sampled the wrong individual: the feces of the targeted female could have been mis-

sampled due to the simultaneity in defecation with a male situated close by.

females $(0.4 \%)$ are encouraging. We found only one case of spurious amplification of the $\mathrm{Y}$ allele in a female of $M$. tavaratra. This case is probably due to a sporadic lab contamination, since two additional PCRs from the same extracted DNA amplified only the $\mathrm{X}$ allele. Even though allelic dropout is frequently a problem with DNA extracted from non-invasive samples (Ensminger and Hoffman, 2002), we detected a very low dropout rate across our three species. The Y fragment dropped out only twice in $M$. tavaratra. Thanks to the replicate approach used in our molecular sexing test, we correctly identified these samples as males (additional PCRs from the same extracted DNA amplified properly the Y fragment). Our study, therefore, provides good examples of the interest and importance of doing replicates of the PCR reactions in order to decrease the probability of sex misassignments (see also Ensminger and Hoffman, 2002). Similarly, Robertson and Gemmell (2006) strongly recommended repeating amplifications of individual samples via a multiple-tubes approach, in order to check for genotyping errors and contaminations, and be able to distinguish the true absence of the sex dependent fragment from its amplification failure, especially when dealing with non-invasive samples. Yet, very few studies developing molecular sexing assays in nonhuman primate taxa (see the references in Table 6) appear to have applied any validation test. Only one study (Bradley et al., 2001) quantified the error rate associated with the nonamplification of the $\mathrm{Y}$ allele in males based on the Sullivan amelogenin gene system and using non-invasive samples of chimpanzees and gorillas. They found very similar values ( $2 \%$ 
452 and 3\%, respectively) to what we found. But we note that they only amplified samples with

$453>25$ pg of genomic DNA, whereas in our study, we tried to amplify all samples whatever the

454 amount of extracted DNA. In addition, some of the validation procedures of the authors

455 remained unclear (in particular, the number of replicates carried out per DNA extraction).

456 Ensminger and Hoffman (2002) also mentioned that they did amplify each extract from

457 invasive sample at least twice and each fecal extracts in triplicate, but they did not provide

458 clear values of their $\mathrm{Y}$ fragment dropout rates for the three great ape species (Pan paniscus, $P$.

459 troglodytes and Gorilla gorilla) that reliably amplified the Amel-A/B primers. Finally,

460 Robertson and Gemmell (2006) investigated the occurrence of sexing errors in studies using

461 PCR-based tests of sex. Unlike the recent interest in microsatellite genotyping errors, they

462 found that very little attention has been paid to molecular sexing errors. Interestingly, among

463 the 16 species for which sexing errors were reported (all from mammalia, aves or

464 Osteichthyes taxa), the lowest error rates were found in the tree swallow (Tachycineta

465 bicolor $)(0.5 \%$, B. Robertson unpubl. data), the chimpanzee and the gorilla (see values

466 mentioned above, Bradley et al., 2001).

467 Robertson and Gemmell (2006) also recommended, especially when dealing with non-

468 invasive samples, to repeat amplifications of individual samples via a multiple-tubes

469 approach, in order to determine the number of independent amplifications necessary to have a

470 high confidence in the results of the sexing test. From our results, we found that the

471 percentage of positive PCRs providing a sexing result different from the final consensus sex

472 was $0.6 \%$ over the three species. This finding means that if a single positive PCR is used to

473 molecularly sex lemur samples, sexing errors will be obtained in slightly more than one

474 sample out of 200 on average. But this value is misleading as it can vary widely according to

475 the species considered. In our study, the sexing error was $1.3 \%$ in M. tavaratra, but $0.0 \%$ in

$476 P$. coronatus and $P$. verreauxi. Adding a single PCR replicate can allow to detect these sexing 
477 errors. In our study, only two M. tavaratra individuals out of 75 were assigned an incorrect

478 sex in the first positive PCR. Repeating the amplification for all individuals enabled us to

479 identify these individuals as having potential sex identification problems, because inconsistent

480 molecular sexing results were found between the first and second positive PCRs. Our results

481 showed that inconsistent sexing results between the first and second positive PCRs are expected in $1 \%$ of the samples over the three species. With two additional sexing replicates,

was identical to the field sex. Interestingly, we also showed that less than $2 \%$ of the total samples showed inconsistent molecular sexing results between the three first positive PCRs and required additional PCRs to obtain the final consensus sex.

As a final test, because it was the species with the highest mismatch between field and molecular sexes, we randomly chose 11 individuals among the $61 P$. coronatus samples (for which we could obtain at least three independent positive PCRs for the first molecular sexing test) and molecularly sexed them a second time using independent PCRs from a different sample collection in the field and extraction in the lab. The final consensus sexing results were identical to the previous ones in all these 11 cases.

In the light of these results, we suggest the following strategy in order to minimize molecular sexing errors and costs (in time and money) when using Di Fiore's lemur sexing test, especially with non-invasive samples. We recommend amplifying twice each individual sample. Each amplification should be done independently to avoid contamination or bias in the sex identification. Whenever the two replicates provide consistent sexing results, the final consensus sex should be based on these two replicates. Whenever the two replicates provide ambiguous sexing results, two additional amplifications should be performed in order to identify the sex with the highest support, which will be retained as the final consensus sex. 
501 In summary, Di Fiore's sexing test based on the co-amplification of the SRY gene with

502 the amelogenin X gene using strepsirhine-specific X primers appears to be an interesting and

503 reliable molecular sexing test for lemurs. First, it has been shown to work thus far on six

504 different lemur species from five different genera and four different families and we may

505 therefore expect that these markers will be universal among lemurs and other primates.

506 Second, we showed that Di Fiore's sexing test works well on degraded DNA obtained from

507 non-invasive samples (at least in $P$. coronatus and $P$. verreauxi). In particular, the results

508 from $P$. verreauxi were extremely good with $100 \%$ success amplification and the markers did

509 not seem to suffer much from technical problems such as allelic dropouts, null alleles or

510 preferential amplification. However, the amount of time between sampling and

511 genotyping/sexing seems to be an important factor. Third, the sexing test can be conducted

512 with a single multiplex PCR, so that it is fast, inexpensive, and requires only small amounts of

513 sample. Hence, the sexing protocol could in principle be performed in Madagascar provided

514 access to a lab where PCRs can be performed is available. Provided that the time between

515 sampling and sexing is short, our results suggest that the success rate would be very high,

516 which stresses again the need to develop local laboratories and train local field biologists to

517 these techniques. Fourth, Di Fiore's lemur sexing test includes an internal positive control

518 (amelogenin X gene) which amplifies in both sexes. Finally, bands are easily visualized on

519 the agarose gel thanks to the large difference of size between bands ( $\sim 35 \mathrm{bp})$. Hence, overall,

520 Di Fiore's sexing protocol fits well the five criteria listed by Villesen and Fredsted (2006a) to

521 define the optimal primate sexing marker. The only minor difference with the "optimality

522 criteria" is that it is not a single marker but the co-amplification of two markers (i.e. the SRY

523 gene and the amelogenin X gene). Among the five markers that have been tested so far for

524 molecular sex identification of non-human primates (i.e. AMEL, zinc finger protein,

525 UTX/UTY gene, Dead-Box and SRY), only one, the UTX/UTY gene, could be considered as 

526 an optimal primate sexing marker, as defined by Villesen and Fredsted 2006b (Table 5). Our
527 study shows that Di Fiore's sexing test based on the co-amplification of the SRY gene with
528 the amelogenin $X$ gene using strepsirhine-specific $X$ primers constitutes an interesting
529 alternative. It would be interesting in the future to compare these two methods (UTX/UTY
530 and SRY / amelogenin X). 
532 CV was funded by a Fundação para a Ciência e a Tecnologia grant (ref. PTDC/BIA-

533 BEC/100176/2008) to LC and by an individual fellowship (ref. SFRH/BPD/73675/2010). JS

534 is funded by an individual FCT fellowship (SFRH/BD/64875/2009). SVM. was funded by an

535 Optimus!Alive-IGC fellowship and CP by the UMR $7206-$ CNRS. This work was partly

536 funded by the Laboratoire d'Excellence (LABEX) entitled TULIP (ANR-10-LABX-41), the

537 Groupement de Recherche International Madagascar and the Institut Francais de la

538 Biodiversité, Programme Biodiversité de l'Océan Indien (reference no. CD-AOOI-07-003).

539 The authors wish to thank all the people, especially M. Andriamampiandrisoa, D. Caillaud, F.

540 Rakotodranaivo and T. Ranaivoson, who assisted with field-work in Madagascar. We also

541 want to acknowledge R. Sharma and M. Carreira from IGC for their guidance and help in

542 labwork, respectively. We would also like to thank the Malagasy government, Madagascar

543 National Parks, and CAFF/CORE for permitting us to conduct this study. MICET, and

544 Professor Lydia Rabetafika of the Department of Animal Biology and Professor Edmond

545 Roger of the Department of Plant Biology and Ecology at the University of Antananarivo are

546 much appreciated for facilitating the research. This study was made in accordance with the

547 laws of the Countries of Portugal, France, USA and Madagascar. 
549 Bailey D, Affara N, Ferguson-Smith M. 1992. The X-Y homologous gene amelogenin maps

550 to the short arms of both the $\mathrm{X}$ and $\mathrm{Y}$ chromosomes and is highly conserved in primates.

551 Genomics 14:203-205.

552 Bastian ML, Brockman DK. 2006. Paternal care in Propithecus verreauxi coquereli. Int J

553 Primatol 28:305-313.

554 Bergl RA, Vigilant L. 2006. Genetic analysis reveals population structure and recent

555 migration within the highly fragmented range of the Cross River gorilla (Gorilla gorilla

556 diehli). Mol Ecol 16:501-516.

557 Boesch C, Kohou G, Nene H, Vigilant L. 2006. Male competition and paternity in wild

558 chimpanzees of Taï Forest. Am J Phys Anthropol 130:103-115.

559 Bradley BJ, Chambers KE, Vigilant L. 2001. Accurate DNA-based sex identification of apes

560 using non-invasive samples. Conserv Genet 2:179-181.

561 Bradley BJ, Doran-Sheehy DM, Lukas D, Boesch C, Vigilant L. 2004. Dispersed male

562 networks in western gorillas. Curr Biol 14:510-513.

563 Bradley BJ, Robbins MM, Williamson EA, Steklis HD, Steklis NG, Eckhardt N, Boesch C,

564 Vigilant L. 2005. Mountain gorilla tug-of-war: silverbacks have limited control over

565 reproduction in multimale groups. Proc Natl Acad Sci USA 102:9418-9423.

566 Constable JJ, Packer C, Collins DA, Pusey AE. 1995. Nuclear DNA from primate dung.

$567 \quad$ Nature 373:393.

568 Constable JL, Ashley MV, Goodall J, Pusey AE. 2001. Noninvasive paternity assignment in

569 Gombe chimpanzees. Mol Ecol 10:1279-1300

570 Di Fiore A. 2005. A rapid genetic method for sex assignment in non-human primates.

571 Conserv Genet 6:1053-1058. 
572 Ensminger AL, Hoffman SMG. 2002. Sex identification assay useful in great apes is not

573 diagnostic in a range of other primate species. Am J Primatol 56:129-134.

574 Eriksson J, Hohmann G, Boesch C, Vigilant L. 2004. Rivers influence the population genetic 575 structure of bonobos (Pan paniscus). Mol Ecol 13:3425-3435.

576 Eriksson J, Siedel H, Lukas D Kayser M, Erler A, Hashimoto C, Hohmann G, Boesch C,

577 Vigilant L. 2006. Y-chromosome analysis confirms highly sex-biased dispersal and suggests a

578 low male effective population size in bonobos (Pan paniscus). Mol Ecol 15:939-949.

579 Fernando P, Melnick DJ. 2001. Molecular sexing eutherian mammals. Mol Ecol Notes 1:350580353.

581 Fredsted T, Villessen P. 2004. Fast and reliable sexing of prosimian and human DNA. Am J

582 Primatol 64:345-350.

583 Gagneux P, Boesch C, Woodruff DS. 1996. Microsatellite scoring errors associated with non584 invasive genotyping based on nuclear DNA amplified from shed hair. Mol Ecol 6:861-868.

585 Gerloff U, Schlötterer C, Rassmann K, Rambold I, Hohmann G, Fruth B, Tautz D. 1995.

586 Amplification of hypervariable simple sequence repeats (microsatellites) from excremental 587 DNA of wild living bonobos (Pan paniscus). Mol Ecol 4:515-518.

588 Gerloff U, Hartung B, Fruth B, Hohmann G, Tautz D. 1999. Intracommunity relationships, 589 dispersal pattern and paternity success in a wild living community of Bonobos (Pan paniscus) 590 determined from DNA analysis of faecal samples. Proc R Soc Lond B 266:1189-1195.

591 Goossens B, Chikhi L, Jalil MF, Ancrenaz M, Lackman-Ancrenaz I, Mohamed M, Andau P, 592 Bruford MW. 2005. Patterns of genetic diversity and migration in increasingly fragmented 593 and declining orang-utan populations from Sabah, Malaysia. Mol Ecol 14:441-456.

594 Goossens B, Chikhi L, Utami SS, de Ruiteret J, Bruford MW. 2000. A multi-samples, multi595 extracts approach for microsatellite analysis of faecal samples in an arboreal ape. Conserv 596 Genet 1:157-162. 
597 Goossens B, Funk SM, Vidal C, Latour S, Jamart A, Ancrenaz M, Wickings EJ, Tutin CEG, 598 Bruford MW. 2002. Measuring genetic diversity in translocation programmes: principles and 599 application to a chimpanzee release project. Anim Conserv 5:225-236.

600 Griffiths R, Tiwari B. 1993. The isolation of molecular genetic markers for the identification 601 of sex. Proc Natl Acad Sci USA 90:8324-8326.

602 Guschanski K, Vigilant L, McNeilage A, Gray M, Kagoda E, Robbins MM. 2009. Counting 603 elusive animals: Comparing field and genetic census of the entire mountain gorilla population 604 of Bwindi Impenetrable National Park, Uganda. Biol Conserv 142:290-300.

605 He L, Zhang Y, Peng H, Li D, Li D. 2010. Genetic diversity of Rhinopithecus roxellana in 606 Shennongjia National Nature Reserve as estimated by non-invasive DNA technology. Acta 607 Ecol Sin 30:4340-4350.

608 Höss M, Kohn M, Pääbo S. 1992. Excrement analysis by PCR. Nature 359:199.

609 Huang W, Chang BHJ, Gu X, Hewett-Emmett D, Li WH. 1996. Sex differences in mutation 610 rate in higher primates estimated from AMG intron sequences. J Mol Evol 44:463-465.

611 Jensen-Seanman MI, Kidd KK. 2001. Mitochondrial DNA variation and biogeography of 612 eastern gorillas. Mol Ecol 10:2241-2247.

613 Laird PW, Zijderveld A, Linders K, Rudnicki MA, Jaenisch R, Berns A. 1991. Simplified 614 mammalian DNA isolation procedure. Nucleic Acids Res 19:4293.

615 Landsoud-Soukate J, Tutin CEG, Fernandez M. 1995. Intestinal parasites of sympatric 616 gorillas and chimpanzees in the Lope Reserve, Gabon. Ann Trop Med Parasitol 89:73-79.

617 Lewis RJ. 2004 Male-female relationships in sifaka (Propithecus verreauxi verreauxi):

618 power, conflict, and cooperation. PhD dissertation, Duke Univ, Durham, NC, USA.

619 Lewis RJ. 2009. Chest staining variation as a signal of testosterone levels in male Verreaux's 620 sifaka. Physiol Behav 96:586-592. 
621 Lewis RJ, Rakotondranaivo F. 2011. The impact of Cyclone Fanele on sifaka body condition

622 and reproduction in the tropical dry forest of western Madagascar. J Trop Ecol 27:429-432.

623 Malaivijitnond S, Hamada Y, Suryobroto B, Takenaka O. 2006. Female long-tailed macaques

624 with scrotum-like structure American. J Primatol 69:721-735.

625 Marriott BM, Smith JC, Jacobs RM, Jones AO, Altman JD. 1996. Calcium, magnesium, and

626 phosphorus content of hair from two populations of rhesus monkeys. Biol Trace Elem Res

$627 \quad 53: 147-165$.

628 Matsubara M, Basabose AK, Omari I, Kaleme K, Kizungu B, Sikubwabo K, Kahindo M,

629 Yamagiwa J, Takenaka O. 2005. Species and sex identification of western lowland gorillas

630 (Gorilla gorilla gorilla), eastern lowland gorillas (Gorilla beringei graueri) and humans.

631 Primates 46:199-202.

632 McGrew WC, Ensminger AL, Marchant LF, Pruetz JD, Vigilant L. 2004. Genotyping aids

633 field study of unhabituated wild chimpanzees. Am J Primatol 63:87-93.

634 Meyler SV, Salmona J, Ibouroi MT, Besolo A, Rasolondraibe E, Radespiel U, Rabarivola C,

635 Chikhi L. 2012. Density estimates of two endangered nocturnal lemur species from Northern

636 Madagascar: New results and a comparison of commonly used methods. Am J Primatol

$637 \quad 74: 414-422$.

638 Mittermeier RA, Wallis J, Rylands AB, Ganzhorn JU, Oates JF, Williamson EA, Palacios E,

639 Heymann EW, Kierulff MCM, Yongcheng L, Supriatna J, Roos C, Walker S, Cortés-Ortiz L,

640 Schwitzer C. 2009. Primates in peril: The World's 25 most endangered primates 2008-2010.

641 Primate Conserv 24:1-6.

642 Morin PA, Wallis J, Moore JJ, Woodruff DS. 1994. Paternity exclusion in a community of

643 wild chimpanzees using hypervariable simple sequence repeats. Mol Ecol 3:469-478. 
644 Morrill BH, Rickords LF, Schafstall HJ. 2008. Sequence length polymorphisms within

645 primate amelogenin and amelogenin-like genes usefulness in sex determination. Am J

646 Primatol 70:976-985.

647 Myers DM. 1993. The behavioural ecology of the golden-crowned sifaka (Propithecus

648 tattersalli). PhD dissertation, Duke Univ, NC, USA.

649 Nakahori Y, Hamano K, Iwaya M, Nakagome Y. 1991. Sex identification by polymerase

650 chain reaction using X-Y homologous primers. Am J Med Genet 39:472-473.

651 Oka T, Takenaka O. 2001. Wild gibbons' parentage tested by non-invasive DNA sampling

652 and PCR-amplified polymorphic microsatellites. Primates 42:67-73.

653 Olivieri G, Sousa V, Chikhi L, Radespiel U. 2008. From genetic diversity and structure to

654 conservation:genetic signature of recent population declines in three mouse lemur species

655 (Microcebus ssp). Biol Conserv 141:1257-1271.

656 Patel ER. 2006. Non-maternal infant care in wild silky sifaka (Propithecus candidus). Lemur

657 News 12:39-42.

658 Pichon C, Tarnaud L, Bayart F, Hladik A, Hladik CM, Simmen B. 2010. Feeding ecology of

659 the crowned sifaka (Propithecus coronatus) in a coastal dry forest in northwest Madagascar

660 (SFUM, Antrema). Lemur News 15:43-47.

661 Pompanon F, Deagle BE, Symondson WOC, Brown DS, Jarman SN, et al. 2012 Who is

662 eating what: diet assessment using next generation sequencing. Mol Ecol 21:1931-1950.

663 Quéméré E, Crouau-Roy B, Rabarivola C, Louis EE Jr, Chikhi L. 2010. Landscape genetics

664 of an endangered primate species within its entire fragmented range. Mol Ecol 19:1606-1621.

665 Quéméré E, Louis E, Ribéron A, Chikhi L, Crouau-Roy B. 2009. Non-invasive conservation

666 genetics of the critically endangered golden-crowned sifaka (Propithecus tattersalli): high

667 diversity and significant genetic differentiation over a small range. Conserv Genet 11:675-

668687. 
669 Radespiel U, Ratsimbazafy JH, Rasoloharijaona S, Raveloson H, Andriaholinirina N,

670 Rakotondravony R, Randrianarison RM, Randrianambinina B. 2011. First indications of a

671 highland specialist among mouse lemurs (Microcebus spp) and evidence for a new mouse

672 lemur species from Eastern Madagascar. Primates 53:157-170.

673 Rakotoarisoa G, Shore G, McGuire S, Engberg S, Louis EE, Brenneman RA. 2006.

674 Characterization of 20 microsatellite marker loci in Coquerel's sifaka (Propithecus

675 coquereli). Mol Ecol Notes 6:1119-1121.

676 Reinartz GE, Karron JD, Phillips RB, Weber JL. 2000. Patterns of microsatellite

677 polymorphism in the range-restricted bonobo (Pan paniscus): considerations for interspecific

678 comparison with chimpanzees (P. troglodytes). Mol Ecol 9:315-328.

679 Robertson BC, Gemmell NJ. 2006. PCR-based sexing in conservation biology: wrong

680 answers from an accurate methodology? Conserv Genet 7:267-271.

681 Sharma R, Goossens B, Kun-Rodrigues C, Teixeira T, Othman N, Boone JQ, Jue NK,

682 Obergfell N, O'Neill RJ, Chikhi L. 2012. Two different high throughput sequencing

683 approaches identify 1 thousands of de novo genomic markers for the genetically depleted

684 Bornean elephant. PLoS ONE 7(11): e49533.

685 Steiper ME, Ruvolo M. 2003. Genetic sex identification of orangutans. Anthropol Anzeiger

$686 \quad 61: 1-5$

687 Sullivan K, Walton A, Kimpton C, Tully G, Gill P. 1993. A rapid and quantitative DNA sex

688 test: Fluorescence-based PCR analysis of X-Y homologous gene amelogenin. Biotech15:637-

689641.

690 Taberlet P, Bouvet J. 1992. Bear conservation genetics. Nature 358:197.

691 Taberlet P, Griffin S, Goossens B, Questiau S, Manceau V, Escaravage N, Waits LP, Bouvet

692 J. 1996. Reliable genotyping of samples with very low DNA quantities using PCR. Nucleic

693 Acids Res 26:3189-3194. 
694 Taberlet P, Mattock H, Dubois-Paganon C, Bouvet J. 1993. Sexing free-ranging brown bears 695 Ursus arctos using hairs found in the field. Mol Ecol 2:399-403.

696 Taberlet P, Waits LP, Luikart G. 1999. Noninvasive genetic sampling: look before you 697 leap. Trends Ecol Evol 14:323-327.

698 Tecot SR, Baden AL, Romine NK, Kamilar JM. 2012. Infant parking and nesting, not 699 allomaternal care, influence Malagasy primate life histories. Behav Ecol Sociobiol (in press) 700 Vallet D, Petit EJ, Gatti S, Levrero F, Menard N. 2008. A new 2CTAB/PCI method improves 701 DNA amplification success from faeces of Mediterranean (Barbary macaques) and tropical 702 (lowland gorillas) primates. Conserv Genet 9:677-680.

703 van der Kuyl AC, Dekker JT. 1996. St Kitts green monkeys originate from West Africa: 704 genetic evidence from feces. Am J Primatol 40:361-364.

705 Vigilant L, Hofreiter M, Siedel H, Boesch C. 2001. Paternity and relatedness in wild 706 chimpanzee communities. Proc Natl Acad Sci USA 98:12890-12895.

707 Vigilant L. 2002. Technical challenges in the microsatellite genotyping of a wild chimpanzee 708 population using feces. Evol Anthrop 11(Suppl 1):162-165.

709 Villesen P, Fredsted T. 2006a. A new sex identification tool:one primer pair can reliably sex 710 ape and monkey DNA samples. Conserv Genet 7:455-459.

711 Villesen P, Fredsted T. 2006b. Fast and non-invasive PCR sexing of primates: apes, Old 712 World monkeys, New World monkeys and Strepsirrhines. BMC Ecol 6:8.

713 Waits LP, Paetkau D. 2005. Noninvasive genetic sampling tools for wildlife biologists: a 714 review of applications and recommendations for accurate data collection. J Wildl Manage $715 \quad 69: 1419-1433$.

716 Wilson JF, Erlandsson R. 1998. Sexing of human and other primate DNA. Biol Chem $717 \quad 379: 1287-1288$.

718 Woodruff DS. 1993. Non-invasive genotyping of primates. Primates 34:33-346. 
TABLE 1. Summary of five molecular sex determination assays.

\begin{tabular}{|c|c|c|c|c|c|c|c|c|}
\hline Sexing markers & Forward primer $\left(5^{\prime}-3^{\prime}\right)$ & Reverse primer (5'-3') & $\begin{array}{l}\text { Band size } \\
\text { for X (bp) }\end{array}$ & $\begin{array}{l}\text { Band size } \\
\text { for } Y(b p)\end{array}$ & $\begin{array}{c}\text { Lemur } s p . \text { for which the } \\
\text { sexing assay was diagnostic }\end{array}$ & $\begin{array}{l}\text { Lemur } s p \text {. for which the } \\
\text { sexing assay was not diagnostic }\end{array}$ & $\begin{array}{l}\text { Does it work on non- } \\
\text { invasive samples? }\end{array}$ & References $^{\mathrm{a}}$ \\
\hline Sullivan Amelogenin gene & $\begin{array}{c}\text { AmelA: } \\
\text { CCCTGGGCTCTGTAAAGAATAGTG }\end{array}$ & $\begin{array}{c}\text { AmelB: } \\
\text { ATCAGAGCTTAAACTGGGAAGCTG }\end{array}$ & 106 & 112 & & Lemur macaco & NA & 1 \\
\hline $\begin{array}{c}\text { Amelogenin } X \text { gene with } \\
\text { Strepsirhine-specific } \\
\text { primers }\end{array}$ & $\begin{array}{l}\text { AmelF1(strep): } \\
\text { TGGCCTCAAGCCTGCATT }\end{array}$ & $\begin{array}{c}\text { AmelR1(strep): } \\
\text { AACATCYTACCTAATCCCCACA }\end{array}$ & $\approx 200$ & & \multirow{2}{*}{$\begin{array}{l}\text { Lemur catta, Mirza coquereli, } \\
\text { Daubentonia madagascariensis }\end{array}$} & & \multirow{2}{*}{ yes? } & \multirow[t]{2}{*}{2} \\
\hline $\begin{array}{l}\text { Sex determination region } Y \\
\text { gene }\end{array}$ & SRY-F1: AGTGAAGCGACCCATGAACG & SRY-F2: TGTGCCTCCTGGAAGAATGG & & $\approx 165$ & & & & \\
\hline Zinc finger protein gene & $\begin{array}{c}\text { ZFSex_F: } \\
\text { AAGTGCCCTCTTGCACATAGAT }\end{array}$ & ZFSex_R: CCTTTTCCTTATGCACCATTT & $\approx 1560$ & $\approx 1137$ & & $\begin{array}{l}\text { Microcebus murinus, Microcebus } \\
\text { berthae, Cheirogaleus medius, Mirza } \\
\text { coquereli, Eulemur fulvus rufus, } \\
\text { Propithecus verreauxi, Lepilemur } \\
\text { ruficaudatus, Lemur catta }\end{array}$ & NA & 3 \\
\hline $\begin{array}{l}\text { Amelogenin gene with } \\
\text { degenerate primers }\end{array}$ & $\begin{array}{c}\text { Amel2_F: } \\
\text { CTCATCCTGGGCACCCTGSTTATATC }\end{array}$ & $\begin{array}{c}\text { AMEL2_R: } \\
\text { GGTACCACTTCARAGGGGTRAGCAC }\end{array}$ & $\approx 1490$ & $\approx 1310$ & $\begin{array}{l}\text { Microcebus murinus, Microcebus } \\
\text { berthae, Cheirogaleus medius, Mirza } \\
\text { coquereli, Eulemur fulvus rufus, } \\
\text { Lepilemur ruficaudatus, Lemur catta }\end{array}$ & Propithecus verreauxi & no? & 3 \\
\hline \multirow{2}{*}{$\begin{array}{l}\text { Ubiquitously transcribed } \\
\text { tetratricopeptide repeat } \\
\text { protein gene }\end{array}$} & \multirow{2}{*}{$\begin{array}{c}\text { UTXY: } \\
\text { TGCTACCTCAGGTGGACAACAAGG }\end{array}$} & $\begin{array}{c}\text { UTY: } \\
\text { TGCTTGTTTCAGGCACCAAGGRTCTATK }\end{array}$ & & 86 & \multirow{2}{*}{$\begin{array}{c}\text { Eulemurfulvus, Mirza coquereli, } \\
\text { Microcebus murinus, Cheirogaleus } \\
\text { medius, Microcebus berthae, Lemur } \\
\text { catta }\end{array}$} & & \multirow{2}{*}{ yes } & \multirow{2}{*}{4} \\
\hline & & $\begin{array}{c}\text { UTX: } \\
\text { CTCGACACTGGCAGTGCTGTTAGG }\end{array}$ & 127 & & & & & \\
\hline
\end{tabular}

The assays presented in this table have all been tested in lemurs by different authors (see last column for the reference)

NA: Not applicable.

${ }^{a}$ References: 1. Ensminger and Hoffman (2002), 2. Di Fiore (2005), 3. Fredsted and Villesen (2004), 4. Villesen and Fredsted (2006b). 
TABLE 2. Storage methods and time and extracted DNA quality.

\begin{tabular}{|c|c|c|c|}
\hline & & & \\
\hline & M. tavaratra & P. coronatus & P. verreauxi \\
\hline Sample type & ear biopsies & feces & feces \\
\hline Storage method & in Queens lysis buffer & dry with silicagel & dry with silicagel \\
\hline Period of collection in the field & July-August 2010 & July-August 2010 & June 2011 \\
\hline Date of arrival in the lab in Lisbon & October 2010 & October 2010 & July 2011 \\
\hline Period of DNA extraction & between January and June 2011 & between April 2011 and January 2012 & October 2011 \\
\hline Time between collection and arrival in the lab & 2-3 months & 2-3 months & 1 month \\
\hline Time between arrival in the lab and extraction & 3-8 months & 6-15 months & 3 months \\
\hline Time between collection and extraction & 5-11 months & 8-18 months & 4 months \\
\hline Number of extracts & 82 & 36 & 74 \\
\hline Mean DNA concentration (ng/ $\mu \mathrm{L})$ & 59 (range $=4-440$ ) & $524($ range $=20-991)$ & 609 (range $=327-1249)$ \\
\hline Mean $\mathrm{A}_{260 / 280}$ ratio & 1.89 (range $=1.38-2.72)$ & $1.98($ range $=1.63-2.17)$ & 1.97 (range $=1.89-2.02$ ) \\
\hline
\end{tabular}

DNA concentration and $\mathrm{A}_{260 / 280}$ were measured with a Nanodrop (Thermo Scientific Nanodrop 1000 spectrophotometer).

Note that for fecal samples, the estimated template DNA includes that of any organism (e.g., fungi, plants, bacteria) present in the feces and is therefore not necessarily a reliable measure of lemur DNA. 
TABLE 3. Amplification success of the amelogenin X gene.

\begin{tabular}{crrrr}
\hline $\begin{array}{c}\text { Number of } \\
\text { successful PCRs }\end{array}$ & M. tavaratra & P. coronatus & P. verreauxi & Total \\
\hline 0 & 0 & 2 & 0 & 2 \\
1 & 0 & 0 & 0 & 0 \\
2 & 0 & 2 & 0 & 2 \\
3 & 75 & 61 & 18 & 154 \\
\hline Total & 75 & 65 & 18 & 158 \\
\hline
\end{tabular}

This tables shows, for each species and when all the three species were pooled, the number of individuals for which $0,1,2$ and $\geq 3$ successful PCR amplification could be obtained (with a limit of 5-8 independent amplifications and 3 independent extractions for a given sample). 
TABLE 4. Sexing results for M. tavaratra, P. coronatus, P. verreauxi.

\begin{tabular}{|c|c|c|c|c|c|c|c|c|c|}
\hline Species & $\begin{array}{l}\text { Consensus } \\
\text { molecular } \\
\text { sex }\end{array}$ & $\begin{array}{l}\text { Number of samples with } \\
\text { mismatching between } \\
\text { field and molecular } \\
\text { sexing results }\end{array}$ & $\begin{array}{l}\text { Total number } \\
\text { of samples }\end{array}$ & $\begin{array}{l}\text { Mismatching } \\
\text { rate (\%) }\end{array}$ & $\begin{array}{c}\text { Number of } Y \\
\text { fragment } \\
\text { dropouts }\end{array}$ & $\begin{array}{c}\text { Number of } Y \\
\text { fragment spurious } \\
\text { amplifications }\end{array}$ & $\begin{array}{c}\text { Total number } \\
\text { of successful } \\
\text { amplifications }\end{array}$ & $\begin{array}{c}\text { Y fragment } \\
\text { dropout rate } \\
(\%)\end{array}$ & $\begin{array}{c}\text { Y fragment spurious } \\
\text { amplification rate } \\
(\%)\end{array}$ \\
\hline \multirow{3}{*}{ M. tavaratra } & Female & 1 & 46 & 2.17 & & 1 & 138 & & 0.72 \\
\hline & Male & 4 & 29 & 13.79 & 2 & & 87 & 2.30 & \\
\hline & Total & 5 & 75 & 6.67 & & & & & \\
\hline \multirow{3}{*}{ P. coronatus } & Female & 1 & 26 & 3.85 & & 0 & 78 & & 0.00 \\
\hline & Male & 8 & 35 & 22.86 & 0 & & 105 & 0.00 & \\
\hline & Total & 9 & 61 & 14.75 & & & & & \\
\hline \multirow{3}{*}{ P. verreauxi } & Female & 0 & 10 & 0.00 & & 0 & 30 & & 0.00 \\
\hline & Male & 0 & 8 & 0.00 & 0 & & 24 & 0.00 & \\
\hline & Total & 0 & 18 & 0.00 & & & & & \\
\hline \multirow{3}{*}{$\begin{array}{l}\text { The three } \\
\text { species } \\
\text { pooled }\end{array}$} & Female & 2 & 82 & \multirow{3}{*}{16.67} & \multirow{3}{*}{2} & 1 & 246 & \multirow{3}{*}{0.93} & 0.41 \\
\hline & Male & 12 & 72 & & & & 216 & & \\
\hline & Total & 14 & 154 & & & & & & \\
\hline
\end{tabular}

Here only the samples with at least three positive PCRs were considered.

The consensus molecular sex represents the sex identified after three consistent results of the positive PCRs. 
TABLE 5. Advantages and drawbacks of the eight different sexing markers tested so far in non-human primates.

(1)

14

5

16

9

19

3

Amelogenin

gene systems

西

34
57
7
4
4
4
4
4
4
4

sex

Sex
Criteria identified by Villesen and Fredsted (2006a) for the "optimal primate sexing marker"

\begin{tabular}{|c|c|c|c|c|c|c|c|c|c|c|}
\hline & & & & & & & & & & \multirow{3}{*}{ References $^{a}$} \\
\hline & \multicolumn{5}{|c|}{ Be diagnostic in a range of primate species } & \multirow{2}{*}{$\begin{array}{c}\begin{array}{c}\text { Amplify small } \\
\text { products } \\
(100-300 \mathrm{bp})\end{array} \\
\begin{array}{c}\text { Work on non- } \\
\text { invasive samples }\end{array}\end{array}$} & \multirow{2}{*}{$\begin{array}{c}\text { Amplify products that } \\
\text { differ substantially in } \\
\text { length }(15-30 \mathrm{bp})\end{array}$} & \multirow{2}{*}{$\begin{array}{c}\text { Amplify diagnostic } \\
\text { products in } 1 \text { step }\end{array}$} & \multirow{2}{*}{$\begin{array}{c}\begin{array}{c}\text { Produce at least } 1 \\
\text { product that exists } \\
\text { in both sexes }\end{array} \\
\text { Provide an internal } \\
\text { positive control }\end{array}$} & \\
\hline & $\begin{array}{l}\text { Great } \\
\text { apes }\end{array}$ & $\begin{array}{l}\text { Lesser } \\
\text { apes }\end{array}$ & $\begin{array}{l}\text { Old World } \\
\text { monkeys }\end{array}$ & $\begin{array}{l}\text { New World } \\
\text { monkeys }\end{array}$ & Prosimians & & & & & \\
\hline $\begin{array}{l}\text { Sullivan amelogenin gene } \\
\text { system }\end{array}$ & $\mathrm{YES}^{\mathrm{b}}$ & YES & NO & NO & NO & YES & NO & YES & YES & $1,2,3$ \\
\hline $\begin{array}{l}\text { Fredsted \& Villesen } \\
\text { amelogenin gene system }\end{array}$ & $?$ & $?$ & $?$ & $?$ & $\mathrm{YES}^{\mathrm{c}}$ & NO & YES & YES & YES & 4 \\
\hline $\begin{array}{l}\text { Primate specific amelogenin } \\
\text { X system }\end{array}$ & YES & YES & YES & YES & NO & YES & NA & YES & NO & 5 \\
\hline $\begin{array}{l}\text { Strepsirhine-specific } \\
\text { amelogenin X system }\end{array}$ & $?$ & $?$ & $?$ & $?$ & YES & $?$ & NA & YES & NO & 5 \\
\hline tein system & YES & YES & YES & YES & NO & NO & $Y_{E S}{ }^{d}$ & YES & YES & $4,6,7$ \\
\hline e & YES & YES & YES & YES & NO & YES & YES & YES & $\mathrm{YES}^{\mathrm{e}}$ & 8 \\
\hline $\begin{array}{l}\text { ranscribed tetratricopeptide } \\
\text { gene }\end{array}$ & YES & YES & YES & YES & YES & YES & YES & YES & YES $^{f}$ & 9 \\
\hline ation region $Y$ gene & YES & YES & YES & YES & YES & YES & YES & YES & NO & $5,10,11,12$ \\
\hline
\end{tabular}


We used the criteria identified by Villesen and Fredsted (2006a) for the "optimal primate sexing marker" (see main text) and applied them to all the different sexing markers tested so far in non-human primates.

${ }^{a}$ References: 1. Bradley et al. (2001), 2. Ensminger and Hoffman (2002), 3. Steiper and Ruvolo (2003), 4. Fredsted and Villesen (2004), 5. Di Fiore (2005), 6. Wilson and Erlandsson (1998), 7. Fernando and Melnick (2001), 8. Villesen and Fredsted (2006a), 9. Villesen and Fredsted (2006b), 10. Steiper and Ruvolo (2003), 11. Malaivijitnond et al. (2007), 12. He et al. (2010).

${ }^{\mathrm{b}}$ but Pongo pygmaeus.

${ }^{\mathrm{c}}$ but Propithecus verreauxi.

$\mathrm{d}$ except prosimians.

${ }^{\mathrm{e}}$ but primer region mutations may be an issue in untested primate species.

${ }^{\mathrm{f}}$ but primer region mutations may result in non-identification of males due to PCR failure.

NA: Not applicable. 


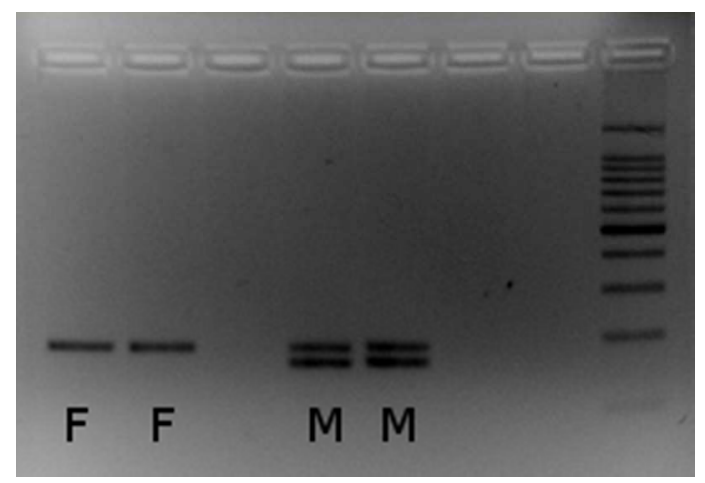

Fig. 1. Gel image of the molecular sexing assay.

This figure shows the result for four faecal samples of Propithecus verreauxi. The assigned sex ( $M=$ male, $\mathrm{F}=$ female) based on the assay of each sample is noted below each lane. The two females (lanes 1 and 2, starting from the left) are identified by a single band (the $X$ fragment) whereas the two males (lanes 4 and 5 ) are identified by two bands (the $X$ and $Y$ fragments). The size standard (100 bp Step ladder PROMG6951$\mathrm{SC}$ ) is shown on the right-most lane (lane 8$)$. $22 \times 15 \mathrm{~mm}(300 \times 300 \mathrm{DPI})$ 